\title{
Estimation of equivalent permeability of snowpack using a snowmelt lysimeter at Patsio, northwest Himalaya
}

\author{
Prem DATT, P.K. SRIVASTAVA, G.K. SOOD, P.K. SATYAWALI \\ Research and Development Centre, Snow and Avalanche Study Establishment, Him Parisar, Sector 37A, \\ Chandigarh 160036, India \\ E-mail: datt_prem@rediffmail.com
}

\begin{abstract}
The meltwater percolation process through the snowpack greatly influences its physical and mechanical properties. The percolation process is important for understanding the spring avalanche phenomenon as well as the meltwater runoff for basin hydrology studies. The permeability of individual snow layers depends on parameters such as porosity, pore connectivity and the geometrical shape of the pores. Snowpack equivalent permeability plays an important role in governing the transmission of meltwater through the different layers of the snowpack. In this paper, we present the design, fabrication and installation of a snowmelt lysimeter at Patsio field research station, Himachal Pradesh, India, and determine the snowpack equivalent permeability using lysimeter discharge data. The snowmelt lysimeter, having a collector area of $6.25 \mathrm{~m}^{2}$ and a high-capacity snowmelt measuring tipping bucket, was installed on flat ground near the observatory with a data acquisition system. Snowmelt discharge measurements were made for two melt seasons, 2006/07 and 2007/08. Snow and meteorological data were collected at $15 \mathrm{~min}$ intervals using a semi-automatic weather station. The hourly surface snowmelt was estimated using an energy-balance approach. The maximum daily discharge was $>2 \mathrm{~mm} \mathrm{w.e.} \mathrm{h}^{-1}$ for most of the observation period. The daily mean wave speed of the meltwater front varied from 109 to $285 \mathrm{~mm} \mathrm{~h}^{-1}$ for a daily mean discharge range of $0.6-1.8 \mathrm{~mm} \mathrm{w} . \mathrm{h}^{-1}$, while wave speeds for a particular melt flux of $2 \mathrm{~mm}$ w.e. $\mathrm{h}^{-1}$ varied between 113 and $486 \mathrm{~mm} \mathrm{~h}^{-1}$. The pore-size distribution index was estimated using the power-fit relation between wave speed and discharge. The equivalent permeability of the snowpack was found to vary between $3.4 \times 10^{-8}$ and $9.9 \times 10^{-12} \mathrm{~m}^{2}$.
\end{abstract}

\section{INTRODUCTION}

The natural snowpack is a layered porous medium. The layered structure is caused by different depositional events and subsequent metamorphic processes, with the result that adjacent layers have different properties. Surface melting and meltwater percolation can further influence the physical and mechanical properties. Movement of meltwater within the snowpack is a complex phenomenon and may lead to various heterogeneities like ice layers, ice lenses, meltfreeze crust and drainage tubes (Sharp, 1951). The permeability of snow, to a large extent, governs water flow across different layers and is a sensitive parameter for hydrological studies including snowmelt runoff models (Shimizu, 1970).

For hydrological runoff applications, the point measurements of permeability are of relatively little use for a snowpack having various layers of distinct physical properties. A snowmelt lysimeter is the only suitable field method for estimating the equivalent permeability of an entire snowpack (Fox and Williams, 1999). A lysimeter collects and measures meltwater outflow from the base of the snowpack. Snowmelt lysimeters have been used to provide physical measurements for testing models of snowpack energy balance and meltwater percolation within the snowpack (Obled and Rossé, 1977; Colbeck, 1979; Marsh and Woo, 1985; Kustas and others, 1994; Kattelmann, 2000; Tekeli and others, 2003). Whitaker and Sugiyama (2005) studied seasonal snowpack dynamics through field measurements using lysimeters for a mountainous catchment. Various authors have estimated the equivalent permeability of a natural snowpack using lysimeter data (Colbeck, 1977; Colbeck and Anderson 1982; Jordan 1983). McGurk and
Kattelmann (1986) compiled snow permeability values estimated by various investigators using different methods, and observed variations by three orders of magnitude.

In this paper, the design and installation of a snowmelt lysimeter at Patsio field research observatory, Himachal Pradesh, India, is presented. The snowmelt generated at the snow surface is estimated based on the energy-balance approach. The modeled surface melt along with the lysimeter discharge data are then used to estimate the equivalent permeability of the snowpack during late winter in 2006/07 and 2007/08.

\section{EXPERIMENTAL SITE AND METEOROLOGICAL MEASUREMENTS}

The research site, Patsio $\left(32^{\circ} 45^{\prime} \mathrm{N}, 77^{\circ} 15^{\prime} \mathrm{E} ; 3800 \mathrm{~m}\right.$ a.s.I. $)$, is located in the Great Himalayan range of the northwest Himalaya, approximately $160 \mathrm{~km}$ from Manali on the Manali-Leh highway (Fig. 1). The site has a continental snow climate characterized by dry atmosphere, relatively low precipitation and very cold temperature conditions (Sharma and Ganju, 2000). It is surrounded by high bare mountains on three sides, with rocks and loose soil strata. The station receives solid precipitation throughout the winter, and the melt season typically begins in the second half of March. A semi-automatic meteorological station, close to the snowmelt lysimeter, was used to record the various snow-meteorological parameters including air temperature, relative humidity, wind speed, incoming solar radiation, reflected solar radiation, total snow depth and snow surface temperature (Datt and others, 2008). The 


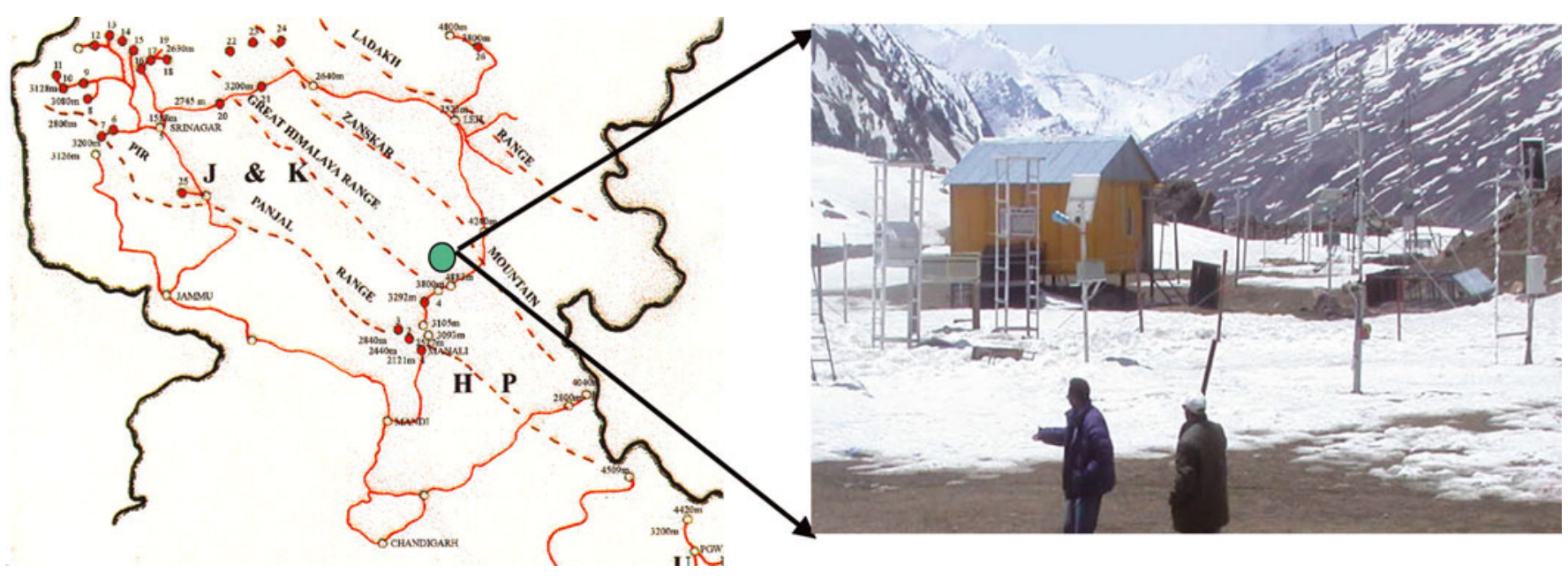

Fig. 1. Observatory at Patsio in Great Himalaya range.

weather station also consists of snow and soil temperature profilers to measure the temperature distribution within the snowpack and soil. All parameters except snow depth are logged at an average interval of $15 \mathrm{~min}$ and snow depth is measured hourly. These snow-meteorological data averaged over 1 hour were used to model surface snowmelt.

\section{DESIGN AND INSTALLATION OF SNOWMELT LYSIMETER}

A snowmelt lysimeter mainly consists of the following components:

\section{Snow collector and drain mechanism}

\section{Meltwater-measuring system}

\section{Data acquisition system}

The snow collector needs to be designed based on type of use and snow conditions at the site where the snowmelt study is to be carried out (Kattelmann, 2000). The collector can be either enclosed or unenclosed, and should be placed on the ground surface before formation of the snowpack. In an enclosed lysimeter, the collector walls are raised on all four sides up to the surface of the snowpack, completely separating the column of snow from the rest of the snowpack. The enclosed lysimeter allows accurate measurements of meltwater produced over the collector since lateral outflow/inflow of snowmelt water is minimized. It is preferred for validating energy-balance models. The drawback, however, is that the side walls can influence the solar energy absorption which can cause increased snowmelt. The unenclosed type of lysimeter has side walls that extend up to $0.1-0.5 \mathrm{~m}$ from the ground, depending on snowpack build-up. Collector area must be adequate to obtain a representative sample of meltwater flux (Kattelmann, 1984). A large-area lysimeter provides a better spatial average of the snowmelt volume and discharge rate than a small-area lysimeter. Male and Gray (1981) proposed that the area of the lysimeter collector should be greater than the square of the snowpack depth. Maximum snow depth recorded for the past 7 years at Patsio (1999/2000 to 2005/06) was used to estimate the dimensions of the snow collector. The mean maximum snow depth was $165 \mathrm{~cm}$ for the above-mentioned period.
An unenclosed lysimeter was selected mainly because we were interested in water percolation (wave speed, permeability, propagation of crust formation, etc.) within the snowpack rather than validating energy-balance models. In addition, our field site experiences wind-drift activity because of dry snow conditions most of the time, and side walls extending above the snow surface would change the snow deposition pattern. Although the lysimeter was placed on flat ground, there may still be lateral inflow/outflow of meltwater. The lysimeter collector has dimensions of $2.5 \mathrm{~m}$ $\times 2.5 \mathrm{~m}$ (Fig. 2), and its walls are raised to a fixed height of $0.5 \mathrm{~m}$ from the ground surface. The collector is made of aluminum metal sheet $2.5 \mathrm{~mm}$ thick. The selected thickness of aluminum sheet is sufficient to sustain the snow load. To prevent the collector from bulging, additional reinforcement was provided to all four aluminum sheets from outside with angle-iron support. The aluminum sheets were coated with white powder so that the collector absorbs a minimum amount of solar radiation.

The base of the snow collector was kept horizontal at ground level with the help of mesh and pebbles, so uniform height of the snowpack builds inside the collector. Two graduated poles were erected at diagonally opposite corners of the collector to measure the snow depth. Meltwater is collected in a U-shaped channel at the centre and drained with the help of an insulated pipe. A tipping bucket placed inside an underground instrument chamber was used to measure the discharge.

\section{EQUIVALENT PERMEABILITY OF SNOWPACK}

Surface snowmelt was estimated using the energy-balance approach. The net energy flux, $\Delta Q$, at the snow surface is given by (Ma and others, 1992)

$$
\Delta Q=S_{\text {in }}+S_{\text {out }}+L_{\text {in }}+L_{\text {out }}+H_{\text {se }}+H_{\text {la }}
$$

where $S_{\text {in, }} S_{\text {out }}$ are incoming and outgoing shortwave fluxes, $L_{\text {in }}, L_{\text {out }}$ are incoming and outgoing longwave fluxes, $H_{\text {se }}$ is the sensible heat flux and $H_{\mathrm{la}}$ is the latent heat flux. The energy flux which comes towards the snow surface is taken positive and the outgoing flux negative.

The amount of snowmelt is calculated by

$$
d_{\mathrm{m}}=\frac{\Delta Q}{\rho_{\mathrm{s}} c \Delta T+L_{\mathrm{f}} \rho_{\mathrm{s}}},
$$




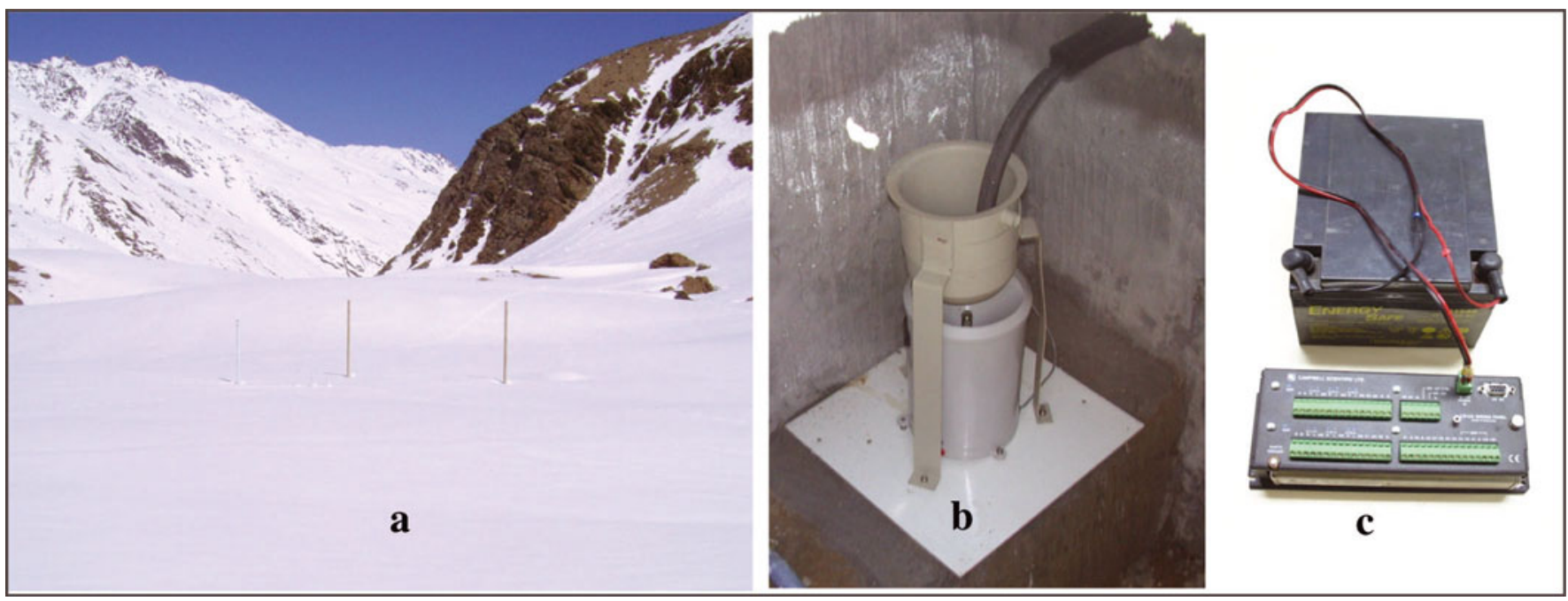

Fig. 2. Snowmelt lysimeter experimental set-up: (a) lysimeter during winter, (b) tipping bucket, (c) data logger.

where $d_{\mathrm{m}}$ is the amount of snowmelt, $\rho_{\mathrm{s}}$ is the average density of snow, $L_{f}$ is the latent heat of fusion, $C$ is the specific heat of snow and $\Delta T$ is the change in temperature required to bring the snow to $0^{\circ} \mathrm{C}$.

The equivalent permeability, $k$, of the snowpack is estimated based on the theory of meltwater percolation within the snowpack (Colbeck 1972, 1975). It is assumed that snow grains are relatively large during the melt season, so that the gravity force dominates and the capillary effects are negligible. If $u$ is the amount of melt flux generated at the surface of the snowpack, its vertical rate of movement $(\mathrm{d} z)$ $\mathrm{d} t)_{u}$ is given by

$$
\left(\frac{\mathrm{d} z}{\mathrm{~d} t}\right)_{u}=\frac{n}{\phi_{\mathrm{e}}}(\alpha k)^{1 / n} u^{n-(1 / n)},
$$

where $n$ is the pore-size distribution index, $\phi_{\mathrm{e}}$ is the effective porosity and $\alpha=5.47 \times 10^{6} \mathrm{~m}^{-1} \mathrm{~s}^{-1}$ is the flow factor. Although the value of $n$ depends on the types of snow, an integral value of $n=3$ has been assumed (Colbeck and Anderson, 1982) for most modeling studies on meltwater percolation through snow.

The equivalent permeability of the snowpack is estimated using Equation (3), which requires estimation of the wave speed $(\mathrm{d} z / \mathrm{d} t)_{u}$ at which a certain surface meltwater flux $u$ moves down through a snowpack of average porosity $\phi_{\mathrm{e}}$. The wave speed is calculated from the depth of the snowpack, $\mathrm{d} z$, and the time lag, $\mathrm{d} t$, between the surface melt and the basal discharge for a given surface meltwater flux $u$. Snow density and snow depth were measured near the lysimeter container, and average values were used for each day. Surface melt was estimated on an hourly basis using meteorological data. The cumulative meltwater flux was measured every $15 \mathrm{~min}$ and hourly discharge was used for analysis. The time lag between surface melt and basal discharge was calculated for different values of melt fluxes for each day.

\section{RESULTS}

Snow-cover build-up and ablation for the 2006/07 and 2007/08 winter seasons at the observatory location are shown in Figure 3. Maximum snow depths of $177 \mathrm{~cm}$ on 12 March 2007 and $176 \mathrm{~cm}$ on 24 February 2008 were recorded. The entire snowpack became isothermal towards the end of March 2007 and around mid-March 2008. Figure 4 shows the variation of air temperature during March and April for each year. The lysimeter discharge data were recorded for a total of 21 days during 15-20 April 2007 and 25 March-30 April 2008. It was observed that the drainage outlet of the lysimeter was blocked for a few days during both seasons because of freezing at the beginning of and sometimes during the melt season. On a few days the tipping bucket overflowed because of heavy meltwater discharge which may be attributed to the sudden breaking of some melt-freeze/ice barrier or possibly to lateral flow from adjacent areas. The data from these periods were not included in the analysis. Maximum daily discharge recorded by the lysimeter was $>2 \mathrm{~mm}$ w.e. $\mathrm{h}^{-1}$ for most days, except for 22 April 2008 when it was $1 \mathrm{~mm}$ w.e. $\mathrm{h}^{-1}$. The maximum discharge was $4.2 \mathrm{~mm}$ w.e. $\mathrm{h}^{-1}$ recorded on 23 April 2008.

Snowpack properties such as snow density, grain size, grain type, hardness index and snow temperature were determined in a nearby snow pit. It was observed that the snowpack was composed of mostly melt-freeze grains/crusts (grain size 1-3 mm) in both years. There was a layer of small rounded grains $(<1 \mathrm{~mm})$ after a snowfall (15-18 April 2008), which very quickly transformed into a melt-freeze layer. The snow density varied between 380 and $520 \mathrm{~kg} \mathrm{~m}^{-3}$, and

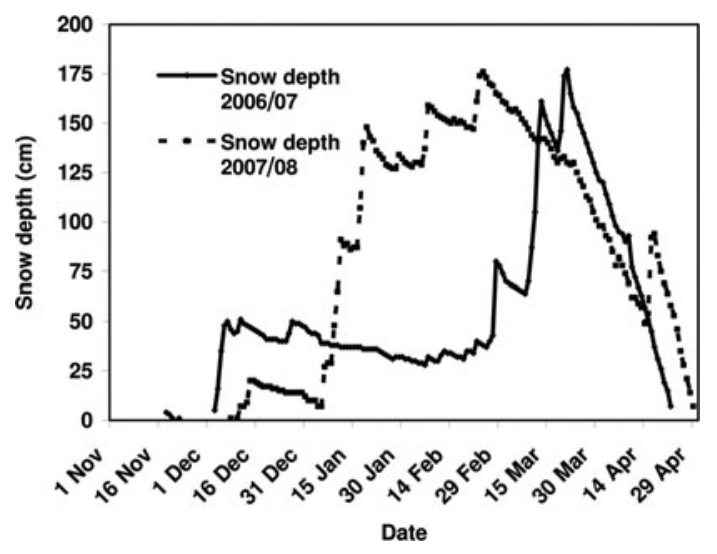

Fig. 3. Snow-cover evolution for $2006 / 07$ and $2007 / 08$ at Patsio station. 


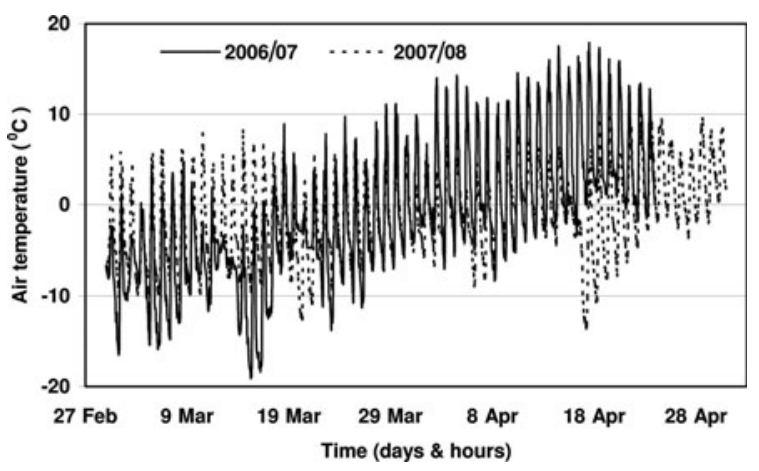

Fig. 4. Variation of air temperature for the snowmelt season (March and April) for 2006/07 and 2007/08 at Patsio station.

effective porosity ranged from 0.40 to 0.54 (assuming an irreducible water saturation of 0.07; Colbeck and Anderson, 1982).

\section{Wave speed}

Time-series plots showing melt estimated the surface and discharge received from the base of the lysimeter were used to calculate the travel time of a particular melt flux within the snowpack. Figure 5 shows one of these plots for a particular day (23 April 2008). The time lag, $d t$, for different values of meltwater discharge, $u$, was calculated from the receding part of the surface melt and the basal discharge curve (McGurk and Kattelmann, 1986). Using measured snow depth $\mathrm{d} z$ and calculated time lag $\mathrm{d} t$, the wave speed $(\mathrm{d} z / \mathrm{d} t)_{u}$ was derived for different values of $u$.

We found wave speeds varying between 82 and $486 \mathrm{~mm} \mathrm{~h}^{-1}$ for meltwater flux values of $1-4.2 \mathrm{~mm}$ w.e. $\mathrm{h}^{-1}$. The daily mean wave speed varied between 109 and $285 \mathrm{~mm} \mathrm{~h}^{-1}$ for a daily mean discharge of $0.6-$ $1.8 \mathrm{~mm}$ w.e. $\mathrm{h}^{-1}$. However, wave speeds for a particular melt flux of $2 \mathrm{~mm}$ w.e. $\mathrm{h}^{-1}$ ranged between 113 and $486 \mathrm{~mm} \mathrm{~h}^{-1}$ for all days. If we remove the outlier with $486 \mathrm{~mm} \mathrm{~h}^{-1}$ which occurred on 21 April 2008, the range of wave speed becomes $113-335 \mathrm{~mm} \mathrm{~h}^{-1}$. Our wave speeds were higher than those reported for a continental snowpack in Colorado, USA $\left(62-177 \mathrm{~mm} \mathrm{~h}^{-1}\right)$, by Fox and Williams (1999). For a melting alpine snowpack in British Columbia, Canada, during late winter, Jordan (1983) reported wave speeds of 250-300 $\mathrm{mm} \mathrm{h}^{-1}$ for a flux of $2 \mathrm{~mm}$ w.e. $\mathrm{h}^{-1}$.

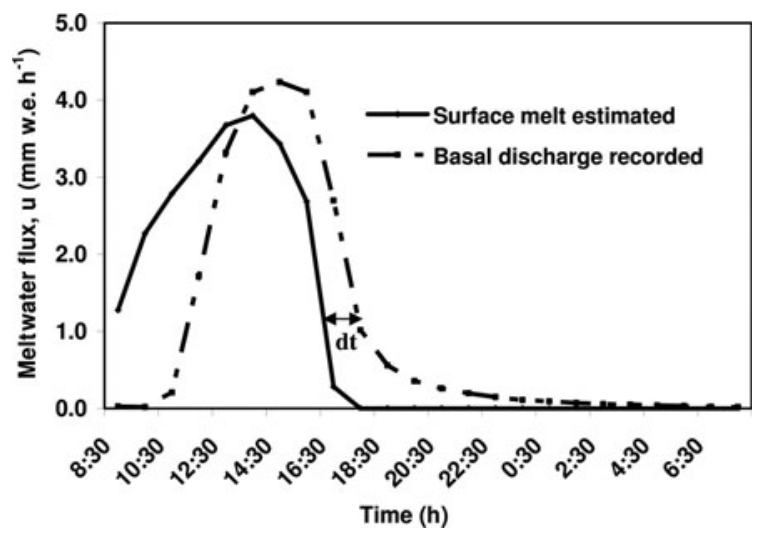

Fig. 5. Surface snowmelt estimated and discharge recorded by the lysimeter at Patsio field station on 23 April 2008.

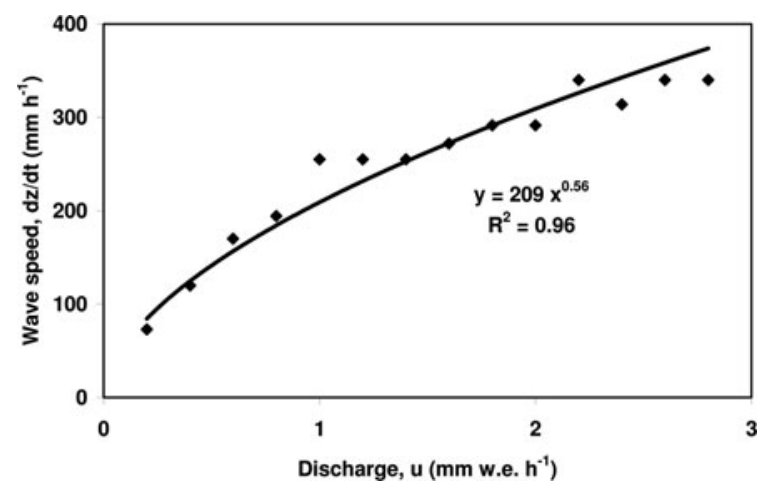

Fig. 6. Power-law fit between discharge $(u)$ and wave speed $(\mathrm{d} z / \mathrm{d} t)$ on 23 April 2008 at Patsio station.

\section{Pore-size distribution index and equivalent permeability}

Figure 6 shows a plot of wave speed $(\mathrm{d} z / \mathrm{d} t)_{u}$ vs discharge $u$ for 23 April 2008. Similar plots were drawn for each day analyzed. The pore-size distribution index $n$ and the equivalent permeability $k$ were estimated by fitting a power-law relation to the data shown in Figure 6 and comparing it with Equation (3). Analysis showed that the pore-size distribution index varied between 1.4 and 3.7, with a mean of 2.05 and standard deviation 0.70 . Fox and Williams (1999) reported values of $n$ ranging from 1.16 to 5.58, while McGurk and Kattelmann (1986) found values ranging between 1.4 and 4.6 . We found no significant trend in the values of $n$ as the melt season progressed. The equivalent permeability varied between $9.9 \times 10^{-12}$ and $3.4 \times 10^{-8} \mathrm{~m}^{2}$, with a mean of $3.5 \times 10^{-9} \mathrm{~m}^{2}$. The highest value of $k$ corresponded to 21 April 2008; removing this outlier, the mean $k$ reduced to $1.2 \times 10^{-10} \mathrm{~m}^{2}$. If a constant value of $n=3$ was assumed, the equivalent permeability ranged between $7.1 \times 10^{-11}$ and $5.1 \times 10^{-9} \mathrm{~m}^{2}$ (Fig. 7). Our values of $k$ were lower than those reported by Colbeck and Anderson (1982) and McGurk and Kattelmann (1986) for a melting snow cover. Fox and Williams (1999) also reported low values of equivalent permeability ranging from $3.23 \times 10^{-12}$ to $6.57 \times 10^{-10} \mathrm{~m}^{2}$. The large range of equivalent permeability can be attributed to the complex interplay between appearance and disappearance of preferential flow paths due to spatial heterogeneities in the form of meltfreeze crusts/ice lenses.

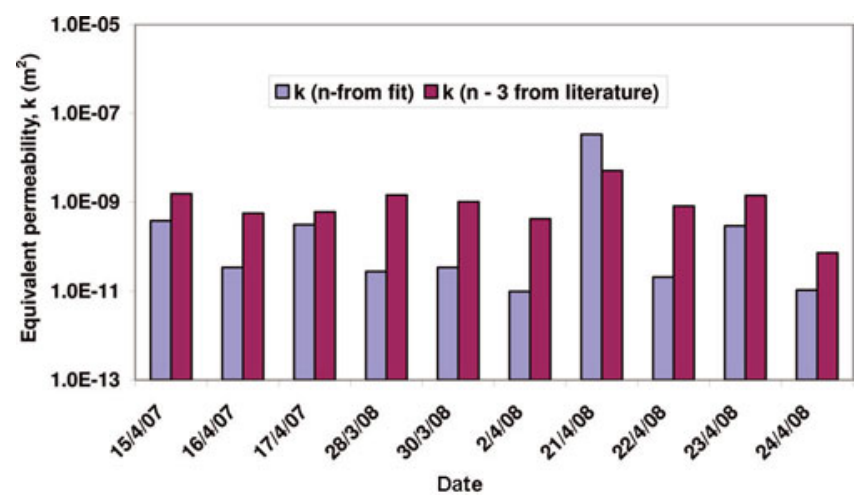

Fig. 7. Equivalent permeability values calculated using the poresize index from fit (i.e. variable) and using a fixed value $(n=3)$. Date format is day/month/year. 


\section{CONCLUSION}

A snowmelt lysimeter was designed and installed, and snowmelt discharge data were recorded from a seasonal snowpack at Patsio field research station. An energy-balance approach was used to estimate surface snowmelt. Maximum daily lysimeter discharge was $>2 \mathrm{~mm}$ w.e. $\mathrm{h}^{-1}$ for most days. Daily mean wave speed of the meltwater front varied between 109 and $285 \mathrm{~mm} \mathrm{~h}^{-1}$ for a daily mean discharge of 0.6-1.8 mm w.e. $\mathrm{h}^{-1}$. Fitting a power-law relation to the discharge and wave-speed data, we estimated the pore-size distribution index to be in the range 1.4-3.7. The equivalent permeability of the snowpack was found to vary between $9.9 \times 10^{-12}$ and $3.4 \times 10^{-8} \mathrm{~m}^{2}$, which is lower than most previously reported values.

\section{ACKNOWLEDGEMENTS}

We thank S. Kumar and V. Kumar for help during field data collection, and J.C. Kapil for helping to improve the manuscript. Thanks are also due to A.C. Whitaker whose insightful comments helped to bring the paper to its present form. This work was supported by the Defence Research Development Organization, India (project No. RD-PI-2004/ SAS-35).

\section{REFERENCES}

Colbeck, S.C. 1972. A theory of water percolation in snow. J. Glaciol., 11(63), 369-385.

Colbeck, S.C. 1975. A theory for water flow through a layered snowpack. Water Resour. Res., 11(2), 261-266.

Colbeck, S.C. 1977. Short-term forecasting of water run-off from snow and ice. J. Glaciol., 19(81), 571-588.

Colbeck, S.C. 1979. Water flow through heterogeneous snow. Cold Reg. Sci. Technol., 1(1), 37-45.

Colbeck, S.C. and E.A. Anderson. 1982. The permeability of a melting snow cover. Water Resour. Res., 18(4), 904-908.

Datt, P., P. Yadav, P.K. Srivastava, P.K. Satyawali and P.S. Negi. 2008. Estimation of snow water equivalent in different climatic zones of N.W. Himalaya. In Venkataraman, G. and R. Nagarajan, eds. Proceedings of the International Workshop on Snow, Ice, Glacier and Avalanches, 7-9 January 2008, Mumbai, India. New Delhi, Tata McGraw-Hill Publishing Company Limited, 34-41.

Fox, A.M. and M.W. Williams. 1999. Equivalent permeability of a continental alpine snowpack. In Troendle, C., ed. Proceedings of the 67th Western Snow Conference, 19-22 April 1999, Lake Tahoe, California. Soda Springs, CA, Western Snow Conference. Jordan, P. 1983. Meltwater movement in a deep snowpack. 2. Simulation model. Water Resour. Res., 19(4), 979-985.

Kattelmann, R.C. 1984. Snowmelt lysimeters: design and use. In Shafer, B.A., ed. Proceedings of the 52nd Western Snow Conference, 17-19 April 1984, Sun Valley, Idaho. Soda Springs, CA, Western Snow Conference, 68-79.

Kattelmann, R. 2000. Snowmelt lysimeters in the evaluation of snowmelt models. Ann. Glaciol., 31, 406-410.

Kustas, W.P., A. Rango and R. Uijlenhoet. 1994. A simple energy budget algorithm for the snowmelt runoff model. Water Resour. Res., 30(5), 1515-1527.

Ma, H., Z. Liu and Y. Liu. 1992. Energy balance of a snow cover and simulation of snowmelt in the western Tien Shan Mountains, China. Ann. Glaciol., 16, 73-78.

Male, D.H. and D.M. Gray. 1981. Snowcover ablation and runoff. In Gray, D.M. and D.H. Male, eds. Handbook of snow: principles, processes, management and use. Toronto, Ont., Pergamon Press Canada, 360-436.

Marsh, P. and M.K. Woo. 1985. Meltwater movement in natural heterogeneous snow covers. Water Resour. Res., 21(11), 1710-1716.

McGurk, B.J. and R.C. Kattelmann. 1986. Water flow rates, porosity and permeability in snowpacks in the central Sierra Nevada. In Kane, D.L., ed. Proceedings of the Symposium on Cold Regions Hydrology, 22-25 July 1986, Fairbanks, Alaska. Bethesda, MD, American Water Resources Association, 359-366. (AWRA Technical Publication Series TPS-86-1.)

Obled, C. and B. Rossé. 1977. Mathematical models of a melting snowpack at an index plot. J. Hydrol., 32(1/2), 139-163.

Sharma, S.S. and A. Ganju. 2000. Complexities of avalanche forecasting in Western Himalaya - an overview. Cold Reg. Sci. Technol., 31(2), 95-102.

Sharp, R.P. 1951. Meltwater behavior in firn on upper Seward Glacier - St. Elias Mountains, Canada. IASH Publ. 32 (General Assembly of Brussels 1951 - Snow and Ice, Vol. 1), 246-253.

Shimizu, H. 1970. Air permeability of deposited snow. Low Temp. Sci., Ser. A 22, 1-32.

Tekeli, A.E., A.A. Sorman, A. Sensoy and A.U. Sorman. 2003. Design, installation of a snowmelt lysimeter and analysis for energy mass balance model studies in Turkey. In Proceedings of the 60th Eastern Snow Conference, 4-6 June, Sherbrooke, Québec, Canada. Hanover, NH, US Army Cold Regions Research and Engineering Laboratory, 43-57.

Whitaker, A.C. and H. Sugiyama. 2005. Seasonal snowpack dynamics and runoff in a cool temperate forest: lysimeter experiment in Niigata, Japan. Hydrol. Process., 19(20), $4179-4200$ 